\section{Usikker nytte for norske medisinstudenter}

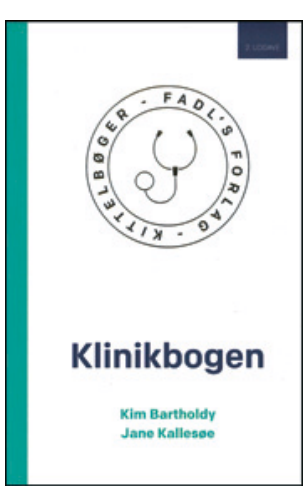

Kim Bartholdy, Jane Kallesøe Klinikbogen

2. utg. 345 s, tab, ill. København: Munksgaard, 2016. Pris DKK 400

ISBN 978-87-7749-848-0

Denne utgivelsen skal gi medisinstudenter kunnskap og gode tips om kliniske undersøkelser samt anamneseopptak. Den er i lommeformat, 345 sider, rikt illustrert og med mange informative tabeller og bokser. Det er 26 kapitler. De seks første omhandler kommunikasjon, journalopptak og mer allmenne symptomer. I de neste 14 kapitlene beskrives symptomer og objektive undersøkelser av ulike organer. Ett kapittel omhandler psykiatriske symptomer og objektive psykiatriske vurderinger.

Det er få kliniske ferdigheter som omtales, og EKG-taking, blærekateterisering og venepunksjon er blant disse. De fleste ferdigheter er nær knyttet opp mot kliniske undersøkelser. Det er litt overraskende at hjerte-lunge-redning ikke er omtalt, heller ikke hvordan man etablerer frie luftveier, legger ned svelgtube og munn-til-maske-ventilasjon. Derimot omtales prosedyrer for bruk av larynxmaske og intubering. Noen av prosedyrene som nevnes, som intubering og spinalpunksjon, er det ikke forventet at våre studenter kan utføre på egen hånd i studietiden, det skjer kun under veiledning eller eventuelt på dukke/fantom. Man ville ha tjent på å ta inn flere praktiske prosedyrer som er en naturlig del av den kliniske undersøkelsen, eksempelvis blodtrykksmåling, urinundersøkelse, inkludert mikroskopi, å lage blodutstryk, ta baketeriologiske prøver, undersøke for blod i avføring og aseptiske metoder, det være seg i mottak, på poliklinikk eller i sengepost.

Boken er lettlest - og jeg oppfatter at språket er godt, til tross for manglende detaljkunnskap om dansk. Teksten skulle være helt uproblematisk for norske studenter. Den er god og nøyaktig, det er nyttige figurer, og layouten er bra. Det er mange gode tips vedrørende kommunikasjon mellom pasient og lege, mellom lege og øvig helsepersonell og, ikke minst, hvordan viktig pasientinformasjon overføres mellom helsepersonell.

Det mest positive er at de kliniske undersøkelsene i ulike fag er samlet mellom to permer - og på et nivå velegnet for studenter. Forfatterne antyder at den kan være oppslagsbok for yngre leger det er jeg i tvil om. Jeg håper kunnskapsnivået og ferdighetene hos nyutdannede leger er såpass gode at det ikke er nødvendig - mer avansert kunnskap kan søkes andre steder.

Jeg er i tvil om jeg skal anbefale Klinikbogen selv om den har et fint formål - jeg er usikker på nytten for vår medisinstudenter. Det er muligens noen som vil føle et behov for en slik bok. Prisen er høy. Anskaffelsen bør i tilfelle skje tidlig i studieforløpet. Norske legestudenter møter tidlig klinisk propedeutikkundervisning, og det finnes både hefter og lærebøker i klinisk propedeutikk tilgjengelig samt norske og engelskspråklige e-læringsressurser i undersøkelsesteknikk.

\section{Praktisk lærebok i gynekologi og obstetrikk for sykepleiere og helsesøstre}

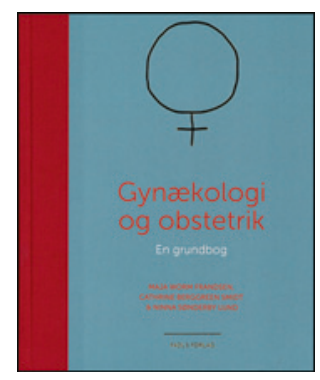

Maja Worm Frandsen, Cathrine Berggreen Smidt, Ninna Sønderby Lund Gynækologi og obstetrikk En grundbog. 341 s, tab, ill. København: FADL'S Forlag, 2016. Pris DKK 300 ISBN 978-87-7749-846-6

Gyncekologi og obstetrikk er forfattet to leger og en sykepleier, alle med undervisningserfaring fra Sex og Samfund og fra undervisning av sykepleierstudenter og medisinstudenter. Navngitte eksperter har fungert som fagfellevurderere innenfor hvert kapittel: 18 leger, en sykepleier og en jordmor. Målgruppen er sykepleiere «med interesse for gynekologi og obstetrikk».

Layouten er oversiktlig og designen god. Det er faste permer med en rød, delikat stoffrygg som gjør at denne danske læreboken kan tåle mye. Illustrasjonene er enkle og relevante og supplerer teksten godt. En unødig negativ detalj er at resymeet på slutten av hvert kapittel er veldig vanskelig å lese på grunn av rød skrift på mørk grå bakgrunn.

Informasjonen er tilpasset dansk lovgivning, dansk klinisk praksis og svangerskapsomsorg, og det vises til nyttige danske nettsteder og dansk litteratur. Forskjeller mellom Danmark og Norge inkluderer lovverket for egg- og sæddonasjon, som er oversiktlig presentert for vårt naboland i kapitlet Infertilitet. Begge deler er tillatt i Danmark, og donorer kan være enten anonyme eller ikke-anonyme. Kapitlet om fosterdiagnostikk beskriver også tilbudet om to rutineultralydsundersøkelser til gravide, mens vi i Norge som kjent tilbyr kun én.

En interessant bagatell er at kapittel 27 omhandler «fødselsbristninger», uten å omtale at forebygging er essensielt for å unngå endetarmsmuskelskader. I Danmark har det vært høy forekomst av slike fødselsskader over flere år, mens vi i Norge effektivt har snudd en tidligere dyster statistikk og ligger nå best an i Norden med en historisk lav forekomst av en skade som kan gi langvarige helseplager. En oppdatert lærebok kunne ha bidratt med denne informasjonen om mulige forebyggingsstrategier, inkludert dem som nå anbefales av danske helsemyndigheter - informasjon som ville ha kommet fremtidige fødegenerasjoner kvinner til nytte.

Forfatternes ambisjoner er at Gyncekologi og obstetrikk kan brukes som grunnbok på sykepleiestudiet samt som oppslagsverk i den kliniske hverdag. Jeg mener den også egner seg godt for norske helsesøstre som jobber med kvinnehelse og kvinnesykdom. Noen av kapitlene kan være relevante for medisinstudenter i Norge, for eksempel kapitlene seksuell dysfunksjon hos kvinner, seksualitet og samtaleteknikk, prevensjonssamtalen, graviditeten uke for uke og seksualitet under graviditet og etter fødselen. Disse temaene er nyttige å ha tenkt på og lest om før pasientsamtaler, og de er som regel utelatt fra vanlig brukte lærerbøker i faget fødselshjelp og kvinnesykdommer.

\section{Annetine Staff}

Overlege, Kvinneklinikken

Oslo universitetssykehus 